\title{
Energy in Swedish industry 2020 - current status, policy instruments, and policy implications
}

Patrik Thollander, Patrik Rohdin, Bahram Moshfegh, Magnus Karlsson, Mats Söderström and Louise Trygg

\section{Linköping University Post Print}

\section{Tweet}

N.B.: When citing this work, cite the original article.

Original Publication:

Patrik Thollander, Patrik Rohdin, Bahram Moshfegh, Magnus Karlsson, Mats Söderström and Louise Trygg, Energy in Swedish industry 2020 - current status, policy instruments, and policy implications, 2013, Journal of Cleaner Production, (51), 109-117.

http://dx.doi.org/10.1016/j.jclepro.2013.01.021

Copyright: Elsevier

http://www.elsevier.com/

Postprint available at: Linköping University Electronic Press

http://urn.kb.se/resolve?urn=urn:nbn:se:liu:diva-96172 
\# of words: 7353

\title{
Energy in Swedish industry 2020 - current status, policy instruments, and policy implications
}

\author{
Patrik Thollander*, Patrik Rohdin, Bahram Moshfegh, Magnus Karlsson, Mats \\ Söderström, Louise Trygg \\ Department of Management and Engineering, Division of Energy Systems \\ Linköping University
}

SE-581 83 Linköping, Sweden

Received

\begin{abstract}
The EU has established so-called 20-20-20 targets, which in relation to energy mean that each Member State shall improve energy intensity levels by 3.3\% annually, leading to a reduced primary energy use of $20 \%$ by the year 2020 , calculated from a projected level based on the primary energy use in 2005. Sweden has established a less ambitious target of $1.7 \%$ annual energy intensity improvement through 2020. The aim of this paper is to evaluate, ex-ante, the EU 2020 primary energy target for the Swedish industrial sector. An applied backcasting methodology is used. The assessment made in this paper is that actions that lead to between 31.6 to $33.2 \mathrm{TWh} /$ year reductions in energy end-use are needed if the EU target is to be achieved. Results from this paper shows that the current energy policy instruments are not sufficient to the EU or Swedish targets. Estimations in this paper are that a primary energy target of about 22.3 TWh/year is reasonable. The paper concludes by presenting a roadmap on how the Swedish 2020 target can be achieved through: i) energy management; ii) energy-efficient technology; and iii) energy supply measures, with an approximate cost of 280-300 MEUR or 75-80 kWh per
\end{abstract}


public EUR. Three major additional policy measures are needed compared with the current policy: including all energy carriers, not just electricity, in the Swedish long-term agreements program PFE; setting up networks; and making it possible for third parties, i.e., industry, to deliver excess heat into the monopolized Swedish district heating grids.

Keywords: Industrial energy efficiency; EU 2020 primary energy target; industrial energy policy; industrial energy efficiency potential; backcasting

\section{Introduction}

The impact of global climate change as a result of greenhouse gas emissions, primarily from the use of fossil fuels, has made EU decision makers act decisively. In 2012, the EU presented the Energy Efficiency Directive (EED). In addition to the EED, the EU has established so-called 20-20-20-targets, which in relation to energy mean that each Member State shall reduce primary energy use by $20 \%$ by the year 2020 , calculated from a projected level ${ }^{1}$ based on the primary energy use in 2005 (EC, 2006b).

The energy end-use in Swedish industry is about $152.4 \mathrm{TWh} /$ year (in 2010) of which nearly $75 \%$ is used in energy-intensive industry. The remaining $25 \%$ is used in the non-energyintensive industry, where the manufacturing industry represents approximately 7\% of Swedish industry's total energy end use (SEA, 2011).

The deregulation of the European electricity market and rising fuel prices on the international energy markets has led to higher energy end-use prices for Swedish industry. Rapid energy price increases have created a risk that Swedish companies will be affected negatively. This applies especially to electricity prices as Swedish industry has had one of the lowest electricity prices in Europe, and therefore to a greater extent than their European competitors has chosen to use electricity over other energy carriers and fuels (Thollander et al., 2010). The

\footnotetext{
${ }^{1}$ The PRIMES model
} 
Swedish electricity prices on the Nordic spot market have risen by $300 \%$ in the past decade (Thollander et al., 2012). Industrial organizations have two possibilities to reduce the negative impact of higher energy prices. One possibility is to negotiate a lower price from the energy supplier, while the second option is to work internally at the company on energy use, where energy efficiency, load management, conversion of electricity to other energy carriers, utilization of excess heat, as well as internal production of electricity and heat, are examples of possible areas to work with (Caffal, 1996; Thollander and Ottosson, 2010).

The impact of global climate change, the EU's efforts to limit greenhouse gas emissions, and the threat to Swedish industry as a result of rising energy prices (electricity in particular), all present strong incentives for both the Swedish government and Swedish industry to start acting forcefully towards a more efficient supply and end use of energy. In order to work proactively to meet the EU 2020 primary energy target for the industrial sector, there is a need to assess the implications for Swedish industry in terms of needs for improved energy efficiency. Evaluation of policy instruments may be carried out in principally two different ways: ex-ante, meaning that the policy is evaluated before the period has ended, and ex-post, meaning that the policy is evaluated after the program. The aim of this paper is to evaluate the fulfillment of the EU 2020 primary energy target for the Swedish industrial sector. To meet this aim, there is a need to assess existing energy policy instruments towards the sector. The aim has therefore been split into three research questions:

1. How many TWh/year need to be saved in Swedish industry in order to achieve the EU 2020 primary energy target?

2. What is a realistic deployment level for Swedish industry up to 2020?

3. How could a realistic roadmap for 2020 look like?

The paper is structured as follows. After the introduction, the EU and Swedish targets are explained. This section is followed by a method section, a presentation of energy use in Swedish industry, and answering of the research questions. The paper then ends with a concluding discussion. 


\section{The EU's and Sweden's 2020 energy targets ${ }^{2}$}

In October 2006, the EU EEAP (Energy Efficiency Action Plan) presented a primary energy savings target of $20 \%$ in 2020 compared to a projected level from the year 2005 (EC, 2006b). The energy intensity in the EU should be reduced by 3.3\% per year. The baseline projection, based on the PRIMES model, is an increase in primary energy use of $0.5 \%$ per year, if structural effects ${ }^{3}$, autonomous effects ${ }^{4}$ and the effects of previous policy are taken into account. If these are not taken into account, the primary energy use is expected to rise by $2.3 \%$ per year, i.e., a decreased energy intensity of $1.8 \%$ per year is expected due to previous policy ( $0.35 \%$ per year), structural effects $(0.6 \%$ per year) and autonomous effects $(0.85 \%$ per year). From the $0.5 \%$ per year baseline projection in the EU's 2020 target, yet another 1.5\% energy intensity reduction annually is expected, in addition to the prevailing trend of $1.8 \%$ decrease per year, which is the impact of new policy and new policy beyond directive.

In the Swedish Government Bill (2009) the national energy target for 2020 is described. The formulation is that: “A goal of $20 \%$ energy efficiency should be achieved by 2020 . The goal is expressed as a sector-wide target of reducing energy intensity by $20 \%$ between 2008 and 2020.” The goal for 2020 is thus set to be an energy intensity decrease of $1.7 \%$ per year (GB, 2009).

The trend of energy intensity for all sectors in Sweden, from 1983 to 2007, is a decrease of 1.2\% per year. Since 1990 the average rate has been about 1.5\% per year. During 2000-2007 it was back to $1.2 \%$ per year (GB, 2009).

One significant difference between the Swedish and EU goal settings are that the Swedish case is considered fulfilled if the energy intensity decreases by about $1.7 \%$ per year. No

\footnotetext{
${ }^{2}$ For a more thorough description of the EU 2020 primary energy target, see EC (2006b). For a more thorough description of the Swedish 2020 energy target, see GB (2009).

${ }^{3}$ Structural effects, defined as net effect of changes in sector mix, such as industrial developments (EC, 2006).

${ }^{4}$ Autonomous effects, defined as changes brought about by natural replacement of technology, energy price changes, etc. (EC, 2006).
} 
discussion is presented in the Government Bill (GB, 2009) about structural effects, autonomous actions and effects of previous instruments. Nor is an explanation given why Sweden's targets are set below the EU's. In summary it appears that Sweden's targets are less ambitious than the EU's.

\section{Method}

The major method used in this paper is backcasting. Backcasting analysis is a method used in energy and environmental studies since the 1970s, first introduced by Lovin's (1976) SEP (Soft Energy Paths) (Robinson, 1982). For a good overview, see Vergragt and Quist (2011). The method is based on an approach where a target level is set and possible ways to reach that target are studied. Quist and Vergragt (2006) and Vergragt and Quist (2011) state that backcasting is about "generating a desirable future, and then looking backwards from that future to the present in order to strategize and to plan how it could be achieved.” This means that instead of the conventional approach to forecast the amount of energy used in a given year, a target is stated on how much energy can be used in a given year, given certain prerequisites, e.g. carbon neutrality, fossil fuel independence, etc. Dreborg (1996) puts it this way: "Typically backcasting is applied on long-term complex issues, involving many aspects of society as well as technological innovations and change. The focus of interest is on a perceived societal problem of great importance such as the vast and growing impacts of transports on the environment.”

Backcasting has previously been used in Canada (Robinson, 1982), the United Kingdom (Mander et al., 2008; Andersson et al., 2008; Anderson, 2001), the Netherlands (Quist and Vergragt, 2006; van den Bosch et al., 2005) and also in Sweden (Svenfelt et al., 2011; Åkerman and Höjer, 2006; Dreborg, 1996). As a future goal is already set by the EU 2020 primary energy target, backcasting may be considered more appropriate than conventional forecasting. The goal however is set for the whole EU economy and not for a specific sector. In that sense, the backcasting method may not be fully applicable without some adjustment. Moreover, from a sustainability point of view, the primary energy target set by the EU is not an end but a means to 
reach the CO2 and renewable energy source (RES) targets. Also, the current study has a considerably shorter time-span than conventional backcasting studies and moreover, unlike e.g. Robinson (1982), has parts of the supply of energy already fixed. Based on conventional backcasting methodologies, e.g. Robinson (1982), there is thus a need initially to assess a realistic sector-specific target, even though a political goal has been set. This paper applies a backcasting methodology inspired by Robinson (1982), but modified in order to respond to the critical issues addressed above on the applicability of backcasting when the study concerns a means, not an end. The backcasting methodology in this paper is as follows:

1. Initially, the set goal is analyzed based on research in the field, and its applicability is critically assessed.

2. The set goal is adjusted, upwards or downwards, based on the outcome of phase 1 leading to a goal that is stable. Step 2 can therefore be seen as a validation of the set target, which then may lead to a new valid target or keeping the old one in place. The second step, not included in e.g. Robinson (1982), may therefore be argued to increase the set target's or goal's validity.

3. The target, set in phase 2 , is then complemented by a roadmap including various energy policy measures on how to reach the set target.

4. The cost of the individual energy policy measures in the roadmap is then outlined leading to a presentation of the total cost for the whole roadmap.

In this study, a primary energy factor of 1.0 for all energy carriers apart from electricity was used. For electricity, a primary energy factor of 1.92 was used based on the primary energy use for Swedish electricity production in 2005 (SEA, 2010). The work is delimited to include the EU 2020 primary energy target and only concerns energy end-use efficiency. Only where supply measures affect energy end-use efficiency are such included. This means that the remaining two 20-20-20-targets, a reduction of carbon dioxide emissions by $20 \%$ and an increase in renewable energy sources (RES) by $20 \%$, were not explicitly included in the study. 
This delimitation has its limitations as the EU 2020 primary energy target cannot be fully decoupled from the RES and carbon dioxide emission targets. Moreover, the study is delimited to cover the Swedish industrial sector. Related to this assumption, it should be noted that the actions of industry do not necessarily need to be the most cost-effective way to meet the target for a Member State because actions in e.g. the transport sector may be more cost-efficient, i.e., the EU 2020 primary energy target refers to a Member States' energy intensity, alternatively $20 \%$ lower primary energy use than the primary energy use in 2005, for which reason an assessment of energy intensity at sector level can be misleading. Nevertheless, the importance of sector-specific studies like the current study cannot be understated as it gives an ex-ante figure of the target.

The EU EEAP has three policy-related parts: previous policy, new policy, and new policy beyond directive (EC, 2006b). The assumption made regarding the EU 2020 primary energy target is that the national Swedish electricity certificate system is included with previous policy. This is due to the fact that it was introduced in 2003, i.e., before 2005, which is the base year for the EU 2020 primary energy target. The impact of the EU ETS in regard to the EU 2020 primary energy target is not conclusive. According to EC (2006b) regarding the so-called autonomous effects, these include measures implemented as a result of rising energy prices. According to the EU EEAP, the indirect effects, i.e., increased energy efficiency due to higher electricity prices as a consequence of the EU ETS, should therefore count as autonomous effects (EC, 2006b). Regarding the direct effects of the EU ETS, i.e., increased energy efficiency as a direct result of the scheme, there are currently no available figures on the impact of the EU ETS, in terms of reduced energy use (Wesselink et al., 2010).

The primary methodology for evaluating the two other categories in the EU EEAP, new policy and new policy beyond directive, has been a literature survey. The PFE (Program for improving energy efficiency in energy-intensive industry), which started January 1, 2005 was included with new policy (Ottosson and Peterson, 2007). The same applies for the energy audit program initiated in April 2010 (Thollander and Dotzauer, 2010), the Environmental Code 
(Johansson et al., 2007), the Ecodesign Directive (EC, 2005) and the Combined Heat and Power (CHP) Directive (EC, 2004). The effects of the PFE and the energy audit program have been included in this study while the effects of the Environmental Code, the Ecodesign Directive, and the Combined Heat and Power (CHP) Directive were excluded. The reason for excluding the Environmental Code was that there are no available figures on what the Environmental Code has led to, or will lead to, in terms of reduced primary energy use. In fact, Johansson et al. (2007) stated that the Environmental Code is a quite slow policy instrument and has not been widely used towards Swedish industry (Johansson et al., 2007). The same applies to the outcomes of the CHP Directive and the Ecodesign Directives. The reason for not taking the latter into account was also that 1) there are no data given for the Ecodesign Directive in regard to the Swedish industrial sector, and ii) the fact that the PFE and the energy audit program already includes a majority of the improvement measures included within the Ecodesign Directive, i.e., if both improvement measures related to the Ecodesign Directive regarding for example electric motors and the PFE were to be taken into account, one would in fact double count figures. Provided data are available in the future, future ex-ante evaluations should try, to the greatest extent possible, to include the above instruments in the analysis.

Energy intensity is defined as primary energy used $\left(\mathrm{E}_{\mathrm{tot}, \mathrm{ind}}\right)$ divided by Gross Domestic Product (GDP) measured in constant prices, see Eq. 1. The numerator of the energy intensity function - primary energy use - can be illustrated by Eq. 2.

$$
E I=\frac{E_{\text {tot, ind }}}{G D P}
$$

where

$$
E_{\text {tot, ind }}=\sum_{i=1 . . I} P_{i} x_{i}+S_{0}
$$

Where $E_{\text {tot, ind }}$ is the industry's annual primary energy use, $P_{i}$ is the production-related primary energy used to produce products, $x_{i}$ is the quantity of products produced, and $S_{0}$ is the 
base load. The denominator - the industry GDP - can, in turn, be calculated in three different ways, either as the sum of all expenditures, as the sum of value added, or as the sum of producers' income. These three means should theoretically provide the same results. If the sum of value added is used, it is defined as the value of goods sold or services, minus materials and energy costs, transportation and other production-related expenses (Worrell et al., 1997).

The definition of energy intensity outlined in Eq. 1 was adopted by the EU in its 2020 EEAP (EC, 2006b). This means that factors that affect GDP will affect the actual outcome of whether a Member State will be able to achieve the goal or not. This research project was not intended to do an econometric analysis of the development of Swedish industry's value added/GDP by 2020. Such a study is important but has been outside the scope of this work. The figures given in the statement of how many TWh/year Swedish industry should use (save) should therefore be taken as an approximate figure, as the actual outcome depends on a number of economic factors and other factors which are not possible to predict beforehand. The projected figures used as the basis for the study were based on the economic development adopted by the EU's 2020 EEAP (2.3\% GDP increase per year in constant prices and an increase in primary energy use of $0.5 \%$ per year).

\section{Ex-ante evaluation of the EU 2020 primary energy target for Swedish industry}

\subsection{Energy use in Swedish industry}

The aggregated final energy use among the approximately 59,000 Swedish industrial companies is about $152.4 \mathrm{TWh} /$ year (year 2010) of which nearly $75 \%$ is used in energyintensive industry including about 600 companies (PWC, 2007). In Fig 1 and Fig 2, the annual energy use in Swedish industry from the 1970s is presented. The figures show that the aggregated energy use has not changed significantly in 40 years, but that a large portion of the fossil fuel use has been reduced and the RES and electricity shares have increased. 


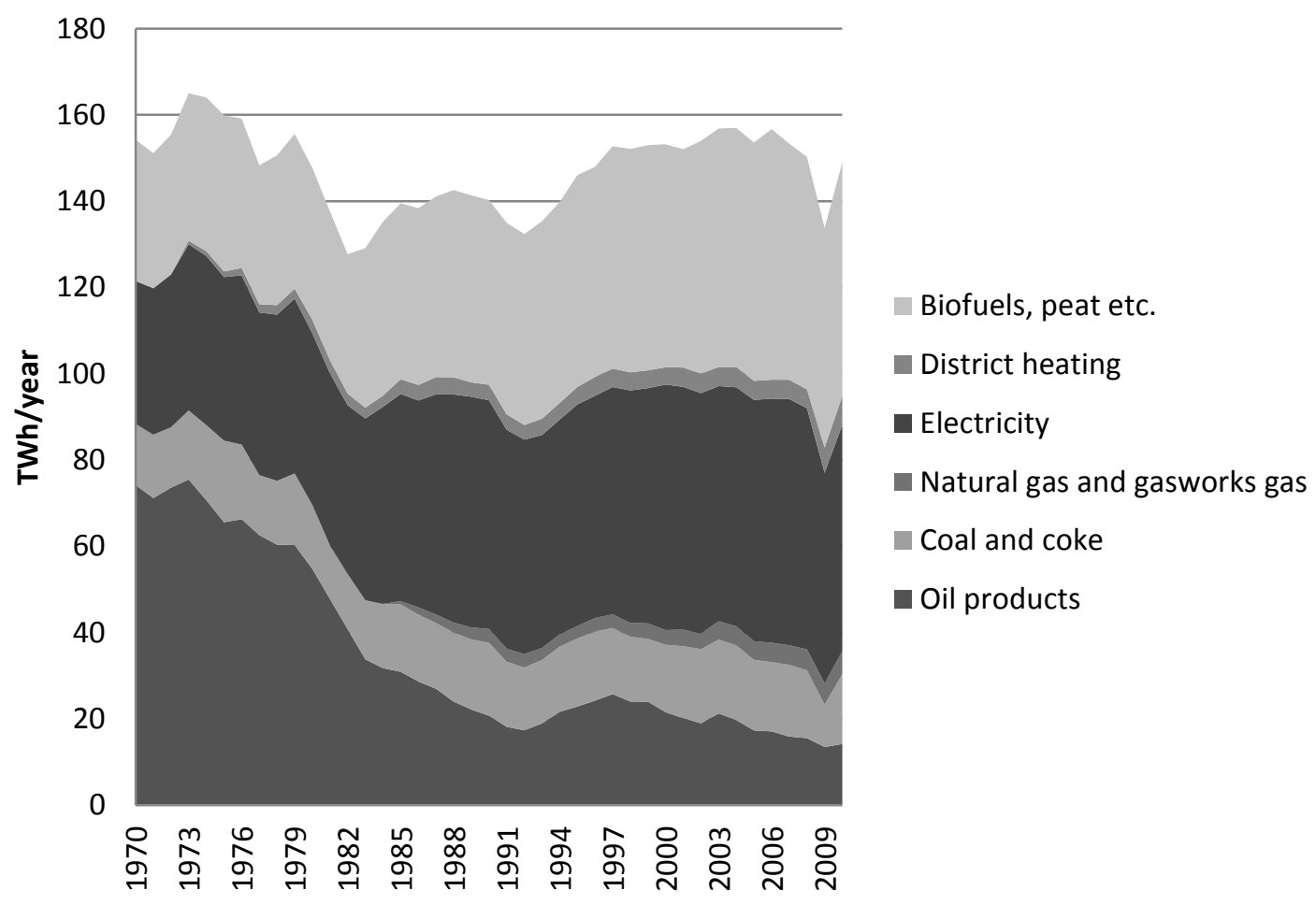

Fig 1. Swedish industry's energy end-use in TWh/year per energy carrier between 19702010 (SEA, 2011).

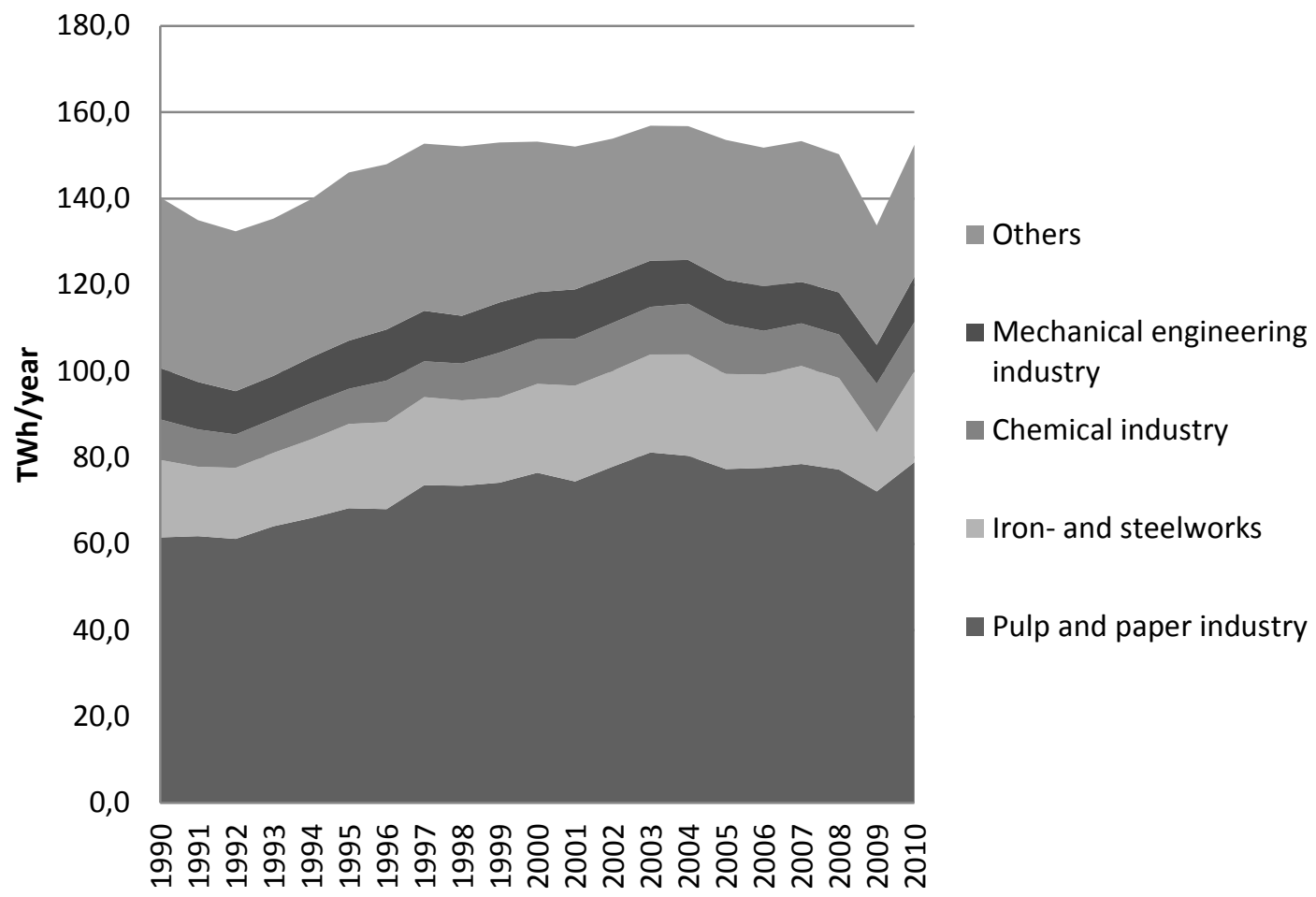

Fig 2. Swedish industry's energy end-use in TWh/year per sector between 1970-2010 (SEA, 2011). 
In Fig 3, Swedish industry's energy intensity from 1993-2008 is presented, showing that the energy intensity has decreased by approximately $2.26 \%$ annually on average.

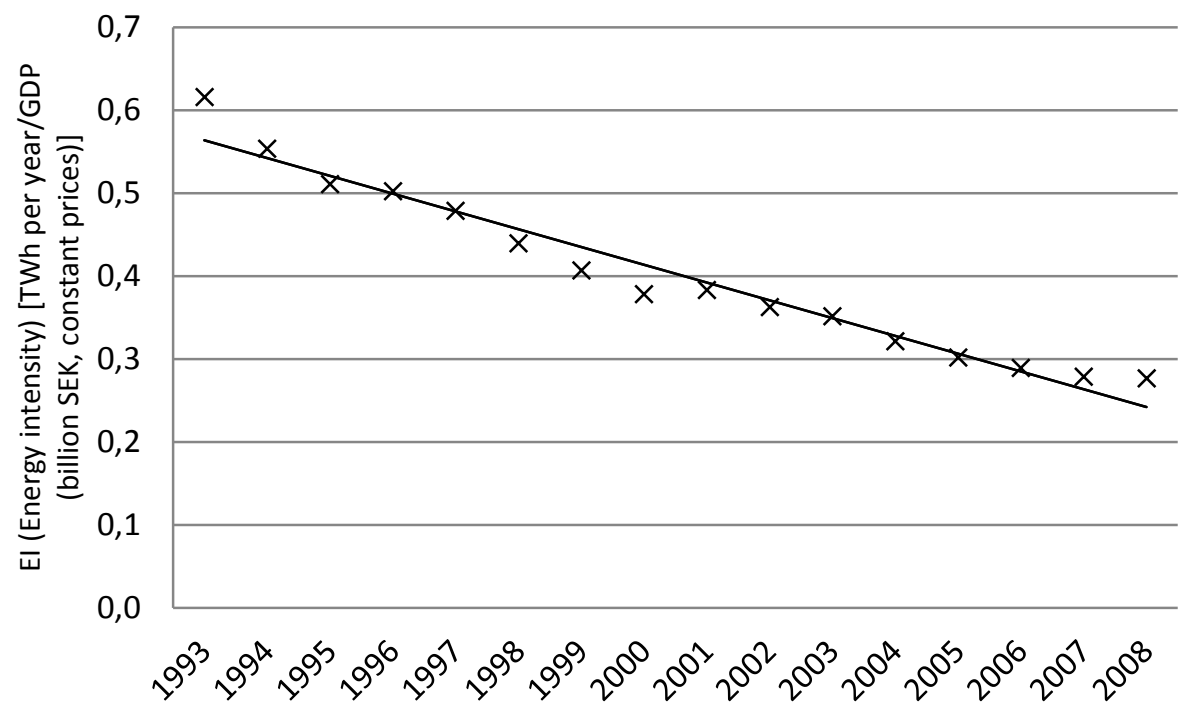

Fig 3. Swedish industry’s energy intensity development between 1993-2008 (SEA, 2010).

\subsection{Effect of already existing energy policy instruments}

Table 1 displays the various energy policies directed towards the industrial sector since 1990 (regional and sector-specific networks excluded).

Table 1

\begin{tabular}{|c|c|c|c|c|c|}
\hline $\begin{array}{l}\text { Energy program, } \\
\text { year }\end{array}$ & $\begin{array}{l}\text { Type of } \\
\text { program }\end{array}$ & $\begin{array}{l}\text { Number of } \\
\text { companies }\end{array}$ & Evaluation & $\begin{array}{l}\text { Subsi- } \\
\text { diaries }\end{array}$ & $\begin{array}{l}\text { Calculated energy } \\
\text { efficiency potential }\end{array}$ \\
\hline $\begin{array}{l}\text { EKO-Energi, 1994- } \\
2001\end{array}$ & $\begin{array}{l}\text { Voluntary } \\
\text { agreements }\end{array}$ & $\begin{array}{l}\text { Approx. } 70 \\
\text { large energy- } \\
\text { intensive }\end{array}$ & Process evaluation & $\begin{array}{l}\text { Public } \\
\text { sponsored } \\
\text { audit }\end{array}$ & N.a. \\
\hline PFE, 2005- & $\begin{array}{l}\text { Long term } \\
\text { agreements }\end{array}$ & $\begin{array}{l}\text { Approx. } 100 \\
\text { energy intensive }\end{array}$ & $\begin{array}{l}\text { Impact } \\
\text { evaluation/process } \\
\text { evaluation. }\end{array}$ & $\begin{array}{l}\text { Tax } \\
\text { discount }\end{array}$ & N.a. \\
\hline $\begin{array}{l}\text { SEA-seminars, } \\
2006\end{array}$ & $\begin{array}{l}\text { Seminars, } \\
\text { information }\end{array}$ & N.a. & $\begin{array}{l}\text { Follow-up } \\
\text { interviews }\end{array}$ & N.a. & N.a. \\
\hline $\begin{array}{l}\text { Project Highland, } \\
\text { 2003-2008 }\end{array}$ & Energy audits & $\begin{array}{l}\text { Approx. } 340 \\
\text { small and } \\
\text { medium-sized }\end{array}$ & Impact evaluation & $\begin{array}{l}\text { Public } \\
\text { sponsored } \\
\text { audit }\end{array}$ & $\begin{array}{l}\text { Electricity savings, } \\
\text { total energy savings }\end{array}$ \\
\hline
\end{tabular}




\begin{tabular}{|c|c|c|c|c|c|}
\hline $\begin{array}{l}\text { Sparkraft, 2000- } \\
2003\end{array}$ & Energy audits & $\begin{array}{l}\text { Mainly service } \\
\text { sector }\end{array}$ & N.a. & $\begin{array}{l}\text { Public } \\
\text { sponsored } \\
\text { audit }\end{array}$ & N.a. \\
\hline $\begin{array}{l}\text { Oskarshamn, 2000- } \\
2001\end{array}$ & Energy audits & $\begin{array}{l}9 \text { largest } \\
\text { companies in } \\
\text { Oskars-hamn }\end{array}$ & Process evaluation & $\begin{array}{l}\text { Public } \\
\text { sponsored } \\
\text { audit }\end{array}$ & $\begin{array}{l}\text { Electricity saving } \\
48 \% \text {, total energy } \\
\text { saving } 40 \%\end{array}$ \\
\hline Elost, & Energy audits & 7 & N.a. & $\begin{array}{l}\text { Public } \\
\text { sponsored } \\
\text { audit }\end{array}$ & $\begin{array}{l}\text { Electricity saving } \\
58 \%\end{array}$ \\
\hline $\begin{array}{l}\text { Energieffektiva } \\
\text { VästraGötaland, - } \\
2005\end{array}$ & Energy audits & 9 & N.a. & $\begin{array}{l}\text { Public } \\
\text { sponsored } \\
\text { audit }\end{array}$ & $\begin{array}{l}\text { Total energy saving } \\
16 \%\end{array}$ \\
\hline $\begin{array}{l}\text { Sustainable } \\
\text { municipalities, } \\
2004-2006\end{array}$ & Energy audits & Approx. 40 & $\begin{array}{l}\text { Impact } \\
\text { evaluation/process } \\
\text { evaluation. }\end{array}$ & $\begin{array}{l}\text { Public } \\
\text { sponsored } \\
\text { audit }\end{array}$ & $\begin{array}{l}\text { Electricity saving } \\
20-60 \% \text {, total } \\
\text { energy saving } 30- \\
38 \%\end{array}$ \\
\hline $\begin{array}{l}\text { The energy audit } \\
\text { check, 2010-2014 }\end{array}$ & Energy audits & Approx. 1000 & $\begin{array}{l}\text { Ex-ante impact } \\
\text { evaluation }\end{array}$ & $\begin{array}{l}\text { Subsidized } \\
\text { energy } \\
\text { audits }\end{array}$ & N.a. \\
\hline
\end{tabular}

Table 1

Swedish industrial energy efficiency programs from 1990-2011 (based on Thollander et al., 2007).

As shown in Table 1, the two major energy end-use policy instruments directed towards Swedish industry are the energy audit program and the PFE. The following sections outline the ex-post figures for the first program period for PFE and ex-ante figures for the energy audit program.

The PFE

The Swedish PFE was introduced in 2005 (Ottosson and Peterson, 2007; Stenqvist and Nilsson, 2011). The policy instrument may be categorized as a classical VA (Voluntary Agreement) or LTA (Long Term Agreement) scheme (Bertoldi and Rezessy, 2011). The first two years, a mandatory energy audit should be conducted. The following three years, an energy management system should be certified and investment routines like life-cycle costs should be used within the organization (Stenqvist and Nilsson, 2011). An ex-post evaluation of the program has been made and the results show that the electricity efficiency improvement 
measures implemented as a result of the program amount to approximately $1.4 \mathrm{TWh} / \mathrm{year}$ and include 1066 measures (SEA, 2010; Stenqvist and Nilsson, 2011). Furthermore, the voluntary reporting of measures related to energy carriers and increased electricity generation has shown an increased electricity production of $1.0 \mathrm{TWh} /$ year (SEA, 2010). As for the so-called free-rider effect of PFE, Stenqvist and Nilsson (2011) have estimated it to be to be approximately $40 \%$ $(30-50 \%)$.

The energy audit program

The energy audit program is a subsidy which went into effect in April, 2010, and can be received through 2014. The aid covers 50\% of the cost of an energy audit, with a maximum of SEK 30,000, and is granted to enterprises using more than $500 \mathrm{MWh}$ of energy per year. To receive the subsidy, enterprises need to (SEA, 2010b):

- formulate an energy plan, including a table of all the improvement measures proposed in the energy audit, and a table that shows which of these improvement measures will be implemented over the next two years.

- write a report describing the energy balance and proposed improvement measures from the energy audit, i.e., results of the energy audit.

- formulate a simple requisition by a statement from the company that the supplied information on costs is accurate.

An ex-ante evaluation of the program stated that it will deliver some 0.7-1.4 TWh/yr in annual energy savings (Thollander and Dotzauer, 2010). As for the so-called free-rider effect of the energy audit program, Thollander and Dotzauer (2010) estimated the effect to be close to zero. This figure is also supported by Väisänen (2003), which in turn was based on an extensive review and experience of 42 energy policies affecting industry throughout Europe. This is among other things due to the fact that the targeted group - small and medium-sized and non- 
energy-intensive industries - are less likely to conduct energy audits and undertake energy efficiency investments than energy-intensive industry (Väisänen, 2003; Shipley and Elliot, 2001).

5.3 How many TWh/year need to be saved in order to achieve the EU 2020 primary energy target?

The assessment made by the authors is that the EU 2020 primary energy target is designed to reduce energy intensity by $1.5 \%$ per annum apart from the $1.8 \%$ per year that occurs due to e.g. structural effects, autonomous effects and the effect of previous instruments. Table 2 displays the effect on energy end-use in Swedish industry as a consequence of the EU 2020 primary energy target.

\begin{tabular}{llll}
\hline Reduced energy end-use $\mathbf{2 0 2 0}$ & & \\
\hline Electricity & 12.7 & $\mathrm{TWh} /$ year \\
Oil products & 3.9 & $\mathrm{TWh} /$ year \\
\hline Natural gas and other industrial gases & 1.0 & $\mathrm{TWh} /$ year \\
District heating & 1.0 & $\mathrm{TWh} /$ year \\
Biofuel, peat, etc, & 12.6 & $\mathrm{TWh} /$ year \\
Coal and coke & 3.7 & $\mathrm{TWh} /$ year \\
\hline Total & $\mathbf{3 4 . 9}$ & $\mathbf{T W h} /$ year \\
\hline
\end{tabular}

Table 2

The effect on energy end-use in Swedish industry as a consequence of the EU 2020 primary energy target.

If the effects of the major energy end-use policy instruments directed towards Swedish industry, the PFE and the energy audit program are deducted from the above table, a slightly lower figure is obtained, from 33.2 to $31.6 \mathrm{TWh} /$ year, see Table 3. 


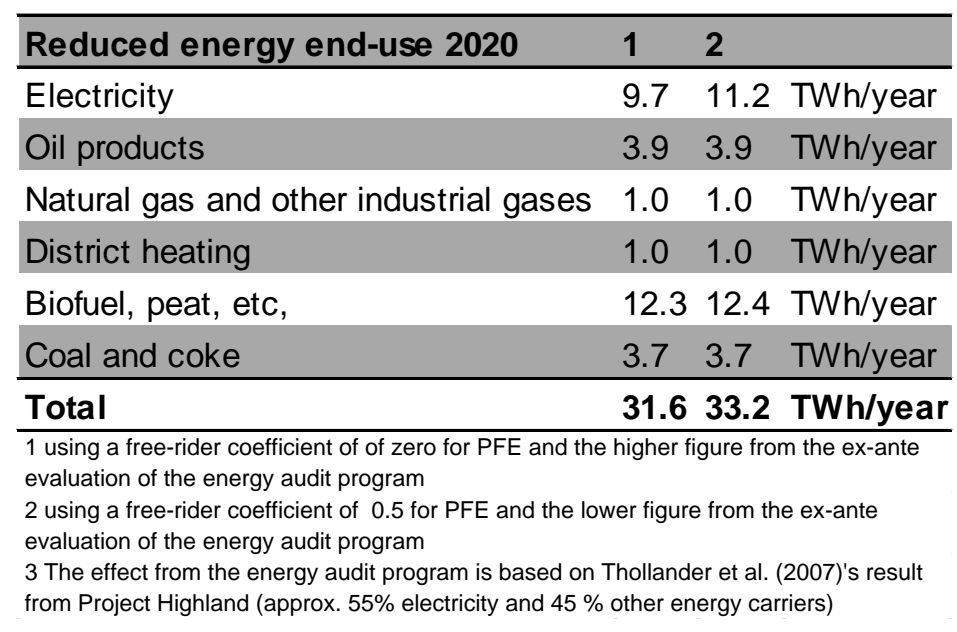

Table 3

The effect on energy end-use in Swedish industry as a consequence of the EU 2020 primary energy target, when the effects of the PFE and the energy audit checks are included.

The EU EEAP estimations are based on the fact that primary energy use is expected to increase by $0.5 \%$ per year and GDP by $2.3 \%$ per year. The EU 2020 primary energy target's implication for Swedish industry, with a primary energy factor for electricity of 1.92 , is illustrated in Fig 4. An increase in primary energy use of $0.5 \%$ per year means that the primary energy end-use in 2020 in Swedish industry is approximately 220.7 TWh per year, see Fig 4. A reduction in energy intensity of $1.5 \%$ per annum (for new policy and new policy beyond directive), in addition to the $1.8 \%$ per year which is assumed to be due to e.g. structural effects, results for Swedish industry in a primary energy use of $176.1 \mathrm{TWh} /$ year in 2020, i.e., a reduction in primary energy use of about $44.5 \mathrm{TWh} /$ year. According to Fig 4, there is a $25.7 \mathrm{TWh} /$ year gap between primary energy in 2008 and primary energy use in 2020. The gap for the year 2009 compared with the year 2020 is only $2.6 \mathrm{TWh} /$ year. This major decrease is explained by the economic recession which began in the fall of 2008 and continued through 2009. In 2010, it was back to the lower line due to the fact that industrial production had started to recover again, increasing by $18.5 \mathrm{TWh} /$ year from 2009 . 


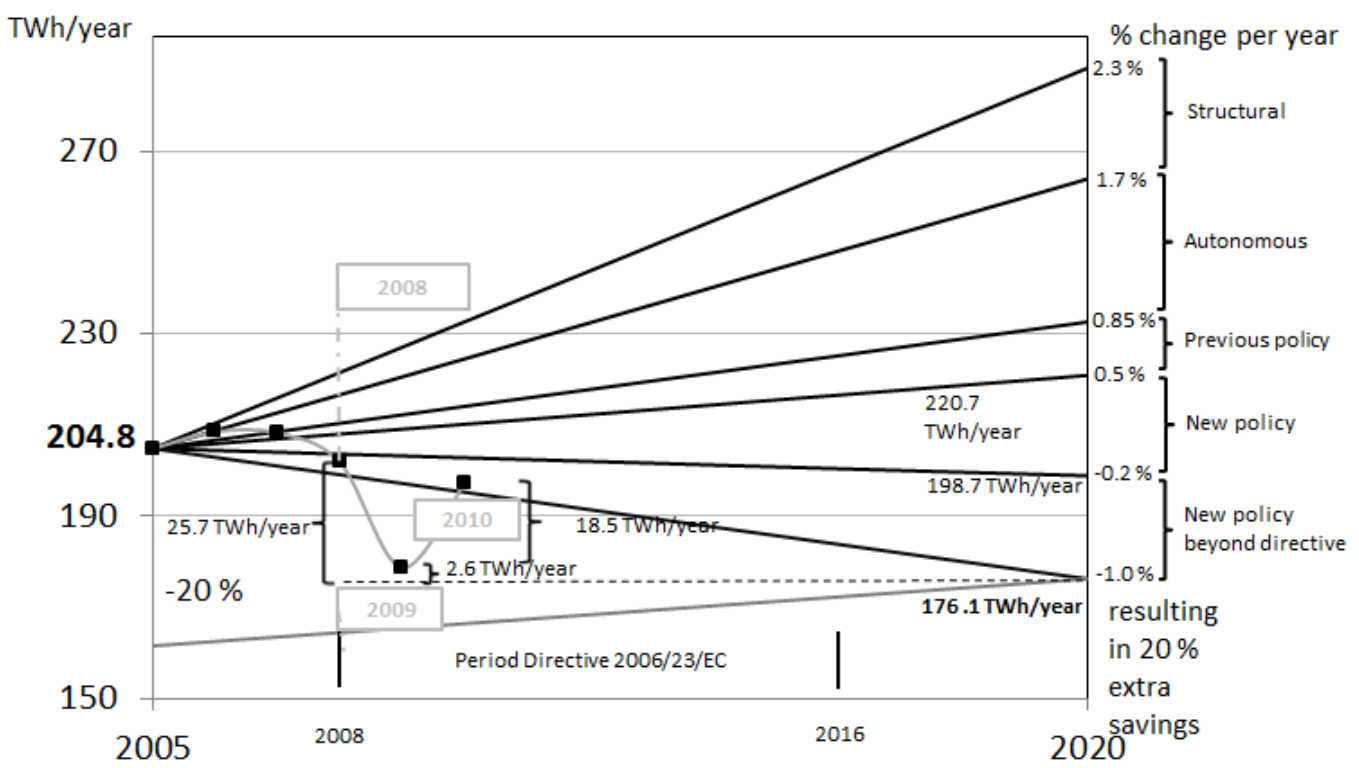

Fig 4. The EU 2020 primary energy target’s implications for Swedish industry. The gray curve represents the actual primary energy use for Swedish industry in the years 2005-2010.

\subsection{What is a realistic deployment level for Swedish industry until 2020?}

The Energy Efficiency Committee (EEC), commissioned by the Swedish Government, has estimated that the energy end-use efficiency potential is about $12.8 \mathrm{TWh} /$ year spread over 6.8 TWh/year for the non-trading parts of the iron and steel, pulp and paper, refinery and petrochemical sectors, and 6.0 TWh/year for the rest of the non-trading parts of the Swedish industrial sector (EEC, 2008). This conservative potential by EEC (2008) includes roughly onethird of the demand for energy end-use savings needed to fulfill the EU 2020 primary energy target for the Swedish industrial sector. Moreover, it is important to emphasize that energy efficiency potential is not equivalent to implementation (Thollander et al., 2012). Studies from Sweden and the United States show implementation rates of $20-50 \%$, i.e., rates of implementation of proposed improvement measures based on an energy audit (Thollander et al., 2007; Corbett et al., 2009; Andersson and Newell, 2004). It is stated in the EU EEAP for 2020 that: "For manufacturing industry, the overall potential is estimated to be around $25 \%$, where peripheral equipment such as motors, fans and lighting offer the most important savings 
potential” (EC, 2006b). This applies to non-energy intensive industry but less so for energyintensive industry. Previous studies based on energy audits in the Finnish pulp and paper industry showed cost-efficient energy efficiency potentials of $1-4 \%$ for electricity and $10-15 \%$ for other energy carriers (Hietaniemi and Ahtila, 2007). Combined with Sweden's relatively high share of industrial energy use in relation to total national energy use, due to a high percentage of energy-intensive industries, this implies that Sweden not only will have difficulty fulfilling the EU 2020 primary energy target for the industrial sector, but moreover implies that Sweden as a member state will have difficulties reaching the EU 2020 primary energy target.

On an EU level, a recession will lead to increased absolute energy savings (Wesserlink et al., 2010). According to the denominator (Eq. 1) of the energy intensity function, this is primarily dependent on the number of goods sold, total revenue from goods sold, minus their related costs. Since the numerator $\mathrm{E}_{\text {tot,ind }}$ has a constant part, $\mathrm{S}_{0}$, which is not directly dependent on the number of goods sold, and the fact that the denominator has a negative fixed part, the fixed costs related to producing a product means that the energy intensity during a recession is not reduced significantly, and instead it is likely to increase. An example of this was the recession of the early 1990s where energy intensity increased between 1990 and 1993 in Swedish industry (SEA, 2010).

Based on previous research (Thollander et al., 2012) and results presented in this paper, it is shown that there is a lack of scientific evidence regarding that the Swedish industrial sector could reach such a high target as stated by the EU. Taking into consideration that the degree of renewability in the whole of Sweden 2020 is expected to be 50\%, a more realistic 2020 target for Swedish industry would thus be around half of the targeted energy end-use figure of 34.9 TWh/year, i.e., 17.5 TWh/year (22.3 TWh/year in primary energy). It should be noted that this target of energy end-use of $17.5 \mathrm{TWh} /$ year is thus in addition to what EC (2006b) refers to as "structural effects and autonomous effects."

5.5 How could a realistic roadmap for 2020 look like? 
As illustrated in Fig 4 and Tables 2-3, the fulfillment of the EU 2020 primary energy target for the Swedish industry, even when the PFE and the energy audit program are included (Table 3) seems far off. This paper shows that such a high target for Swedish industry may be too optimistic up to 2020. If taking into account the large degree of energy-intensive industry in Sweden and the high degree of renewability in Swedish industrial energy use, a deployment level, or target, possible for Swedish industry to handle is a primary energy-saving figure of 22.3 TWh/year up to 2020. This is about half of the implications for Swedish industry when dividing the EU 2020 primary energy target into sectors, i.e., industry, transport, and the building and service sectors. However, it should be noted that RES is a limited resource and that the use of RES in industry is not necessarily the most appropriate use, i.e., more efficient use of RES is of course desirable. The question that remains is, when applying backcasting to this target, how could this roadmap look like? Fig 5 is an attempt to present such a roadmap for Swedish industry.
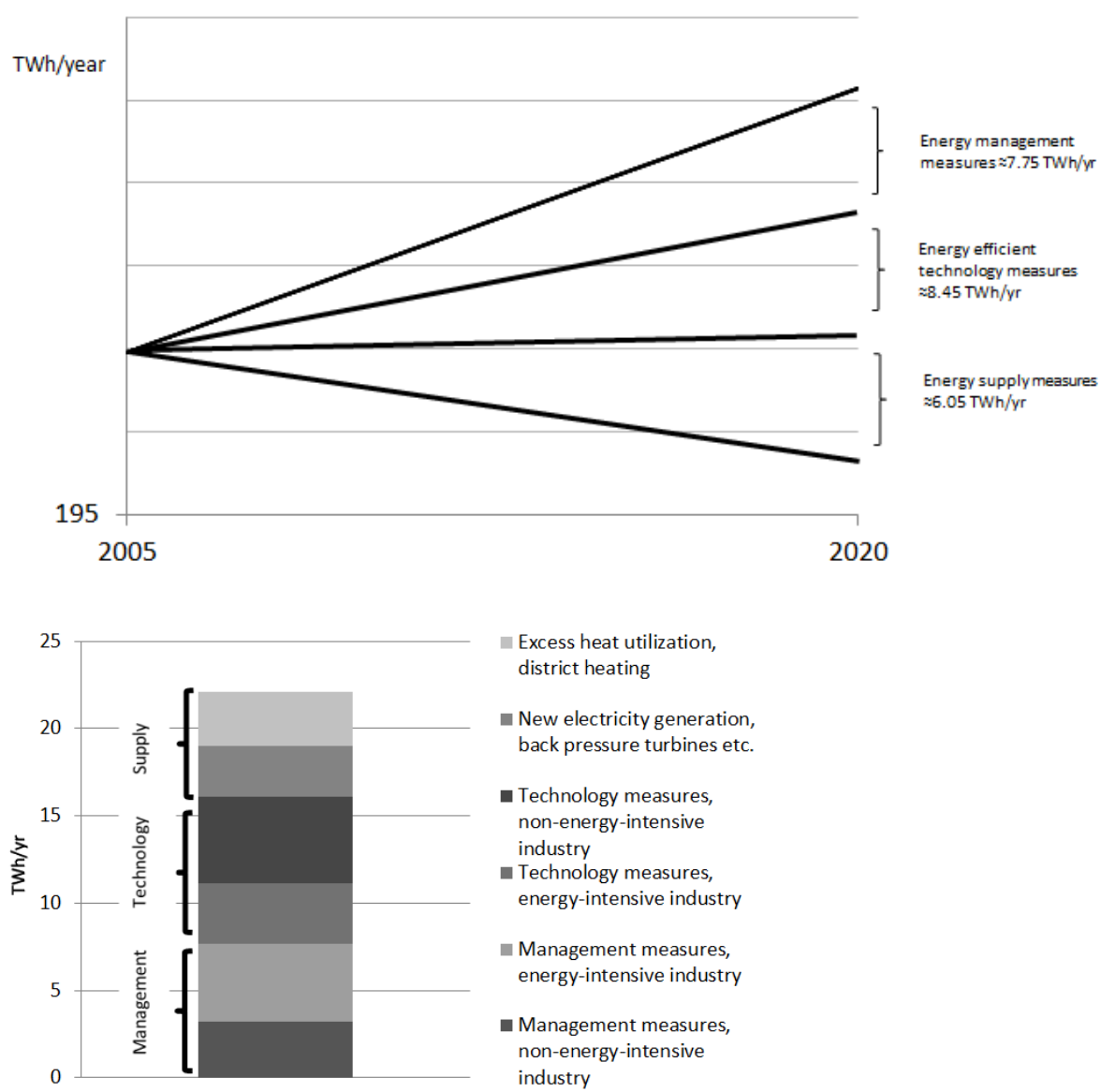

Fig 5. A roadmap for 2020 for Swedish industry. 
The roadmap is divided into three parts: management, process technology, and supply technology measures. The energy management and energy end-use technology potentials for Swedish industry, presented by Backlund et al. (2012a-b) and the energy supply part related to the potential for excess heat utilization presented by Cronholm et al. (2009) and Broberg et al. (2012), have been divided by a factor of two, in order to achieve a plausible deployment level, i.e., potential is not equivalent to deployment. For the supply side measures related to electricity generation, assuming that the electricity certificate scheme is included, a linearization based on the results from 2005 to 2011 up to 2020 has been made.

An extended PFE which includes all energy carriers is likely an effective part of such a policy mix - including both management and technology improvement measures - since the instrument is already running and has been preceded by a long process regarding legislative changes, industry acceptance, etc., and partly because it covers such a large part of Swedish industry's energy end-use. Based on findings from Hietaniemi and Ahtila (2007), showing costefficient energy end-use efficiency potentials of $1-4 \%$ for electricity and $10-15 \%$ for other energy carriers, a future PFE including other energy carriers, apart from electricity, is likely to increase the impact from the PFE greatly.

The current energy audit program would also lead to improved energy efficiency and is a cornerstone for the industrial SMEs in such a roadmap. Apart from the above-mentioned PFE and the energy audit program, the Ecodesign Directive will also provide technology improvement results. Moreover, energy networks or clusters - targeting both management and technology improvement measures - is another policy means proven successful in Switzerland and Germany, both for energy-intensive and non-energy-intensive industrial SMEs (Koewener et al., 2011). Moreover, the introduction of an Energy Management System, such as ISO 50001 and EN 16001, will also contribute to improvements related to both management and technology (Thollander and Palm, 2012). Finally, the electricity certificate scheme promoting RES 
electricity supply will also play a key role in this transition ${ }^{5}$, together with increased excess heat utilization delivering district heating to nearby towns and cities through the introduction of TPA (Third Party Access). TPA means that the DH (district heating) grid, currently a monopoly in Swedish DH grids, is opened up, enabling industrial companies with available excess heat to deliver the heat to the DH grid.

The cost for the roadmap

The estimated cost for the roadmap is presented in fig 6 .

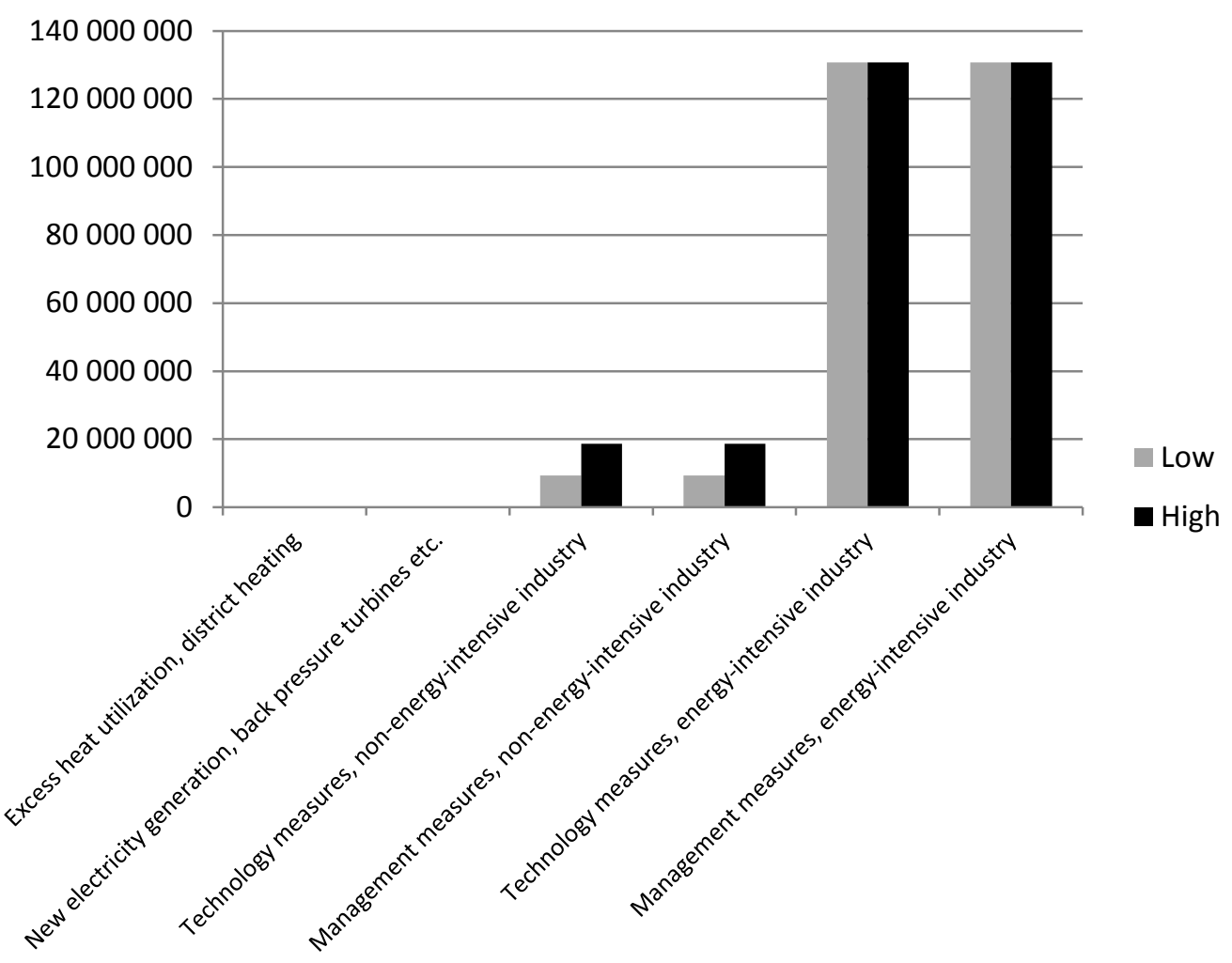

Fig 6. The cost for the roadmap for 2020 for Swedish industry. The high and low estimates are dependent on the span presented in Thollander and Dotzauer (2010).

\footnotetext{
${ }^{5}$ Please note that in a roadmap based on the Swedish 2020 target, the electricity scheme may not be exempted from the calculations.
} 
As for the supply measures which will affect the energy end-use efficiency, the public cost for electricity certificate system and a TPA for the district heating grids may be assumed to be zero or close to zero as it is the market, i.e., the end users, who cover the cost for those measures. As for the technology-related measures, a PFE including all energy carriers is assumed to be the most important instrument for energy-intensive industry, and the cost is assumed to be the same as for the current program using an electricity tax exemption as a driver (Stenqvist and Nilsson, 2011). For non-energy-intensive industry, the current energy audit program is assumed to lead to the major energy efficiency technology measures. The cost is assumed to be the same as the current energy audit program's high and low ex-ante estimations (Thollander and Dotzauer, 2010). As for the management-related measures, it is assumed to be covered within the PFE for energy-intensive industry and thus the cost is assumed to be split in half for technology measures from the PFE in order to avoid double-counting. As for management measures for non-energy-intensive industry, it is assumed to carried out by networks, which by e.g. Koewener et al (2011), has shown to double the degree of adoption of energy efficiency measures, compared with an energy audit program. This leads to an approximate cost for the roadmap of about 280-300 MEUR or around 75-80 kWh primary energy per public EUR. Compared with the current energy policy mix, three major changes are needed: a PFE including all energy carriers, not just electricity; networks; and TPA opening up the monopolized Swedish district heating grids.

\section{Concluding discussion}

The results from this study show that if the EU 2020 primary energy target is to be achieved, it will lead to significant changes in energy supply and energy end-use in Swedish industry. The two major policy instruments related to energy efficiency currently in operation are the PFE and the energy audit program. Results referred to in this paper show that these are not sufficient to meet the target. The assessment made in this paper is that apart from what EC (2006b) refers to as "structural effects and autonomous effects," actions that lead to between 
31.6 to $33.2 \mathrm{TWh} /$ year reductions in energy end-use are needed, if the target is to be achieved. These results imply that bio energy use should decrease. It is important however to point out that the other 20-20-20 targets (reduced carbon dioxide emissions and increased shares of RES) are not decoupled from the energy case, see for example NEP (2010). However, by definition, according to the target of increased shares of RES, decreased RES use affects the RES target negatively. In relation to this, it should also be mentioned that RES is a limited resource and that the use of such in industry is not necessarily the most appropriate use, i.e., more efficient use of RES is of course desirable. However, it does have implications for the other targets. The results should therefore be viewed in light of this.

Taking into consideration that the degree of renewability in the whole of Sweden 2020 is expected to be $50 \%$, i.e. considerably higher than the most EU Member States, and the fact that a large share of the Swedish industrial energy use already today is based on RES, both directly and indirectly through the use of electricity from, e.g. hydro power, a more realistic 2020 target for Swedish industry would thus be around half of the spotted energy end-use figure of 34.9 TWh/year, i.e. 17.5 TWh/year (22.3 TWh/year in primary energy). It should be noted that this target of energy end-use of $17.5 \mathrm{TWh} /$ year is thus in addition to what EC (2006b) refers to as "structural effects and autonomous effects."

The proposed roadmap for Swedish industry presented in this paper, which was based on backcasting and a set primary energy target of $22.3 \mathrm{TWh} /$ year, not taking into account for example structural effects, etc. in the economy, includes the three cornerstones: energy management, energy efficiency technologies, and energy supply measures, expected to be realized by policies which have an aggregated cost of 280-300 MEUR, or 75-80 kWh per public EUR. Three major changes are needed compared with the current policy mix in order for the roadmap to be carried out: a PFE including all energy carriers, not just electricity; networks; and TPA opening up the monopolized Swedish district heating grids. 
A general outcome of this paper is that a realistic level of deployed energy efficiency potential could be to use the EU 2020 primary energy target, and multiply it by a factor based on the degree of RES of the total energy supply in 2020.

In conclusion, the assessment made in this paper is that actions that lead to between 31.6 to 33.2 TWh/year reductions in energy end-use are needed if the EU target is to be achieved. Without the impact of a recession, this paper concludes that this target will be hard to achieve. Estimations in this paper are that a primary energy target of about $22.3 \mathrm{TWh} /$ year is more realizable.

\section{Acknowledgments}

Sincere thanks to the Swedish Energy Agency for funding of this research project. Moreover, we would like to express our appreciation to the three anonymous referees whose useful comments have improved the quality of this paper considerably. The usual disclaimer applies.

\section{References}

Anderson, S.T., Newell, R.G., 2004. Information programs for technology adoption, the case of energy-efficiency audits. Resource and Energy Economics 26 (1), 27-50.

Backlund, S., Broberg, S., Ottosson, M., Thollander, P., 2012a. Energy efficiency potentials and energy management practices in Swedish firms. In ECEEE 2012 Industry Summer Study.

Backlund, S., Thollander P, Palm, J., Ottosson, M., 2012b. Extending the energy efficiency gap. Accepted for publication in Energy Policy. 
Bertoldi, P., Rezessy, S., 2011. Voluntary agreements in the field of energy efficiency and emission reduction, Review and analysis of experiences in the European Union. Energy Policy 39 (11), 7121-7129.

Broberg, S., Backlund, S., Karlsson, M., Thollander, P., 2012. Industrial excess heat deliveries to Swedish district heating networks - Drop it like it’s hot. Accepted for publication in Energy Policy.

Caffal, C., 1996. Energy management in industry. Centre for the Analysis and Dissemination of Demonstrated Energy Technologies (CADDET). Analysis Series 17. Sittard, The Netherlands.

Corbett, C., Muthulingam, S., Benartzi, S., Oppenheim, B., 2009. Adoption of Profitable Energy Efficiency Related Process Improvements in Small and Medium Sized Enterprises. In Proceedings of the 5th European conference on economics and management of energy in industry (ECEMEI-5).

Cronholm, L.Å., Grönkvist, S., Saxe, M., 2009. Spillvärme från industrier och värmeåtervinning från lokaler [Waste heat from industry and heat recycling from offices], Rapport 2009:12. Svensk Fjärrvärme AB [In Swedish].

Dreborg, K.H., 1996. Essence of backcasting, Futures 28, 813-828.

EC (European Commission), 2004. Directive 2004/8/EC of the European Parliament and of the Council of 11 February 2004 on the promotion of cogeneration based on a useful heat demand in the internal energy market and amending Directive 92/42/EEC.

EC (European Commission), 2005. Directive 2005/32/EC of the European Parliament and of the Council of 6 July 2005 establishing a framework for the setting of ecodesign requirements for 
energy-using products and amending Council Directive 92/42/EEC and Directives 96/57/EC and 2000/55/EC of the European Parliament and of the Council, 2005.

EC (European Commission), 2006b. Communication from the Commission. Action Plan for Energy Efficiency, Realizing the Potential. COM (2006) 545 final.

EC, 2006a. Directive 2006/32/EC of the European Parliament and of the Council of 5 April 2006 on energy end-use efficiency and energy services and repealing Council Directive 93/76/EEC, Brussels.

EEC (Energy Efficiency Committee), 2008. Vägen till ett energieffektivare Sverige [The road to a more energy-efficient Sweden]. SOU 2008,110. Stockholm [in Swedish].

GB (Government Bill), 2009. En sammanhållen energi- och klimatpolitik [An aggregated energy and climate policy]. Prop. 2008/09,163. Stockholm [in Swedish].

Hietaniemi, J., \& Ahtila, P., 2007. Energy conservation agreements within Finnish pulp and paper industry - methods and results. Retrieved October 8, 2007, from the Motiva website, http,//www.motiva.fi/attachment/f16d4d543f99d7a59f54560a69063a0e/ dcda18330aa306eb8 3d12fd3b6e09cbd/PP2004-teksti.pdf http,//www.motiva.fi/en/projects_and_campaigns/save_ii_-projects.

Johansson, B., Modig, G., Nilsson, L.J., 2007. Policy instruments and industrial responses experiences from Sweden. In Proceedings of the 2007 ECEEE summer study, Panel 7, 14131421.

K.L. Anderson, 2001. Reconciling the electricity industry with sustainable development, backcasting - a strategic alternative. Futures 33, 607-623 
K.L. Anderson, S.L. Mander, A. Bows, S. Shackley, P. Agnolucci, P. Ekins, 2008. The Tyndall decarbonisation scenarios - Part II, Scenarios for a 60\% CO2 reduction in the UK, Energy Policy 36, 3764-3773.

Koewener, D., Mielicke, U., Jochem, E., 2011. Energy efficiency networks for companies concept, achievements and prospects. In Proceedings of ECEEE 2011 Summer Study. Energy efficiency first, The foundation of a low-carbon society, 725-733.

NEP (Nordic Energy Perspectives), 2010. Towards a Sustainable Nordic Energy System. 20 Perspectives on Nordic Energy Opportunities and Challenges. Final report for the second phase of the Nordic Energy Perspectives project.

Ottosson, C., Peterson, K., 2007. First results from the Swedish LTA programme for energy efficiency in industry. (Paper presented at the 2007 European Council for an Energy-Efficient Economy (ECEEE) summer study “Saving energy - just do it”, Panel 7, 1517-1525.

PWC, 2007. Incitamentsformer för ökade energieffektiva investeringar utanför energiintensiv industri [Incentive forms for increased energy efficiency investments outside of energy-intensive industry]. Örhlings Pricewaterhouse Coopers, Stockholm.

Quist, J., Vergragt, P. J., 2006. Past and future of backcasting: the shift to stakeholder participation and a proposal for a methodological framework, Futures 38, 1027-1045.

Robinson, J.B, 1982. Energy backcasting A proposed method of policy analysis. Energy Policy 10 (4), 337-344. 
S.L. Mander, A. Bows, K.L. Anderson, S. Shackley, P. Agnolucci, P. Ekins, 2008. The Tyndall decarbonisation scenarios - Part I, Development of a backcasting methodology with stakeholder participation, Energy Policy 36, 3754-3763.

SEA (Swedish Energy Agency), 2010. Energy in Sweden 2010. Swedish Energy Agency Publication Department, Eskilstuna.

SEA (Swedish Energy Agency), 2011. Energy in Sweden 2011. Swedish Energy Agency Publication Department, Eskilstuna.

SEA, 2010b. Homepage of the Swedish Energy Agency. Retrieved June 1, 2011, from the Swedish Energy Agency website, www.energimyndigheten.se

Shipley, A.M., Elliot, R.E., 2001. Energy Efficiency Programs for Small and Medium Sized industry. In Proceedings of the 2001 ACEEE summer study on energy efficiency in industry, vol. 1, 183-196.

Stenqvist, C., Nilsson, L.J., 2011. Energy efficiency in energy-intensive industries-an evaluation of the Swedish voluntary agreement PFE. Energy Efficiency (in press).

Svenfelt, A., R. Engstrom, and O. Svane, 2011. Decreasing energy use in buildings by $50 \%$ by 2050 - A backcasting study using stakeholder groups. Technological Forecasting and Social Change, 78 (5), 785-796.

Thollander P, Palm J, 2012. Improving energy efficiency in industrial energy systems - an interdisciplinary perspective on barriers, energy audits, energy management, policies \& programs. Springer (forthcoming) 
Thollander P, Rohdin P, Moshfegh B, 2012. On the formation of energy policies towards 2020, challenges in the Swedish industrial and building sectors. Energy Policy 42, 461-467.

Thollander, P., Dotzauer, E., 2010. An energy efficiency program for Swedish industrial smalland medium-sized enterprises. Journal of Cleaner Production 18 (13), 1339-1346.

Thollander, P., Ottosson, M., 2010. Energy management practices in Swedish energy-intensive industries. Journal of Cleaner Production 18(12),1125-1133.

Thollander, P, Svensson I.L, Trygg L, 2010. Analyzing variables for district heating collaborations between energy utilities and industries. Energy 35(9): 3649-3656.

Thollander, P., Rohdin, P., Danestig, M., 2007. Energy policies for increased industrial energy efficiency, Evaluation of a local energy programme for manufacturing SMEs. Energy Policy 35 (11), 5774-83.

van den Bosch, S., Brezet, H., Vergragt, P., 2005. Rotterdam case study of the transition to a fuel cell transport system. Fuel Cells Bulletin 6:10-16.

Vergragt, P. J., Quist J., 2011) Backcasting for sustainability: Introduction to the special issue. Technological Forecasting and Social Change 78(5): 747-755.

Wesselink, B. et al.., 2010. Energy Savings 2020. How to triple the impact of energy savings in Europe. Final version. Retrieved September 22, 2010 at http,//www.roadmap2050.eu/attachments/files/1EnergySavings2020-FullReport.pdf

Worrell, E., Price, L., Martin, N., Farla J., Schaeffer, R., 1997. Energy intensity in the iron and steel industry, a comparison of physical and economic indicators. Energy Policy 25, 727-744. 
Väisänen, H., (coordinator), 2003. Guidebook for Energy Audit Programme Developers. Retrieved March 22, 2010. from, http,//www.motiva.fi/en/projects_and_campaigns/save_ii_projects.

Åkerman, J. and M. Höjer, 2006. How much transport can the climate stand? Sweden on a sustainable path in 2050. Energy Policy 34 (14), 1944-1957. 